\title{
Soil thermal properties influenced by perennial biofuel and cover crop management
}

\begin{abstract}
Heat transport is an important factor that can influence the soil environment. The objective of this study was to determine if perennial biofuel and cover crops could alter soil thermal properties. Experimental treatments included two levels of cover crops (cover crops [CC] vs. no cover crops) [NC], collectively called row crops (RC), and two biofuel crop treatments. Cover crops used included cereal rye (Secale cereale L.), hairy vetch (Vicia villosa subsp. villosa), and Austrian winter pea [Pisum sativum subsp. arvense (L.) Asch. \& Graebn]. The two biofuel treatments included perennial biofuel crops (PB): giant miscanthus (Miscanthus $\times$ giganteus J.M. Greef \& Deuter ex Hodkinson \& Renvoize) and switchgrass (Panicum virgatum L.). Soil samples were collected at $10-\mathrm{cm}$ depth increments from the soil surface to a depth of $30 \mathrm{~cm}$. Soil thermal properties (thermal conductivity $[\lambda]$, volumetric heat capacity $[\mathrm{CV}]$, thermal diffusivity $[\mathrm{D}])$, and volumetric water content $(\theta)$ were determined at $0,-33$, 100 and $-300 \mathrm{kPa}$ soil water matric potentials. Additionally, bulk density and soil organic C (SOC) were determined. Results showed that PB had $11 \%$ higher CV at saturation, probably because they had significantly higher $\theta$ and SOC than RC management. Cover crops had $13 \%$ higher $\mathrm{CV}$ at saturation probably because they had significantly higher $\theta$ and SOC than no cover crop management. Row crops had significantly higher $\lambda$ and D than PB. The results from the current study imply that $\mathrm{CC}$ and $\mathrm{PB}$ can change soil thermal properties by reducing $\lambda$ and $\mathrm{D}$ and increasing $\mathrm{CV}$ under laboratory conditions.
\end{abstract}

Keyword: Soil thermal properties; Soil environment; Heat transport; Biofuel 
